\title{
Eco-friendly Self-cooling System of Porous Onggi Ceramic Plate by Evaporation of Absorbed Water
}

\author{
Hiroaki Katsuki, Eun-Kyong Choi, Won-Jun Lee, Ung-Soo Kim, \\ Kwang-Taek Hwang, and Woo-Seok Cho ${ }^{\dagger}$ \\ Ceramicware Center, Korea Institute of Ceramic Engineering and Technology, Icheon 17303, Korea
}

(Received January 15, 2018; Revised February 18, 2018; Accepted February 22, 2018)

\begin{abstract}
Porous ceramic plates were prepared from Onggi clay and bamboo charcoal powder at 1100 and $1200^{\circ} \mathrm{C}$ and their porous properties and water absorption, and the cooling effect of porous plates, were investigated to produce eco-friendly porous ceramics for a self-cooling system that relies on the evaporation of absorbed water. Porous properties were dependent on the particle size of charcoal powder pore forming additive and the firing temperature; properties were also found to be dependent on the total pore volume, average pore size and porosity, which had values of $0.103-0.243 \mathrm{~cm}^{3} / \mathrm{g}, 0.81-2.56 \mathrm{~mm}$ and $20.9-38.2 \%$, respectively, at $1100^{\circ} \mathrm{C}$ and $0.04-0.18 \mathrm{~cm}^{3} / \mathrm{g}, 0.33-2.03 \mathrm{~mm}$ and $10.8-30.9 \%$, respectively, at $1200^{\circ} \mathrm{C}$. Cooling temperature difference of flowing air parallel to surface of porous ceramic plates fired with two kinds of charcoal powder at $1100^{\circ} \mathrm{C}$ was $3.5-3.6^{\circ} \mathrm{C}$ at $26^{\circ} \mathrm{C}$ and $60 \%$ of relative humidity in a closed box. Cooling temperature difference was dependent on the number of porous plates and the distance between porous plates. A simple and eco-friendly cooling system using porous ceramic plates fired from Onggi clay and charcoal powder was proposed.
\end{abstract}

Key words : Raw material, Onggi clay, Porous ceramic plate, Evaporative cooling system, Water absorption

\section{Introduction}

$\mathrm{H}$ istorically, a common method of direct evaporative cooling for buildings using water has been found in many parts of the Middle East including ancient Persia and in Egypt, in the form of the 'Maziara jar', which consists of window screens that were built with holes or niches for water jars. The airflow around the porous jars, which were prepared with local clay, evaporates the water and depresses its temperature.

The cooling effect achieved by the evaporation of absorbed water from porous ceramic materials can be used to cool buildings, as well as pavement bricks for local heat islands during summer season. These materials that lead to evaporative cooling have been developed using porous ceramics made from several materials such as alumina, low grade silica, cordierite, glass and some silicate wastes. ${ }^{1-15)}$

In developing countries of Africa, the Middle East, India and Southeast Asia, a very simple, cheap and ecofriendly cooling system using cheap local raw materials and without using electrical energy for cooling is required. ${ }^{16)}$ In our previous study, we found that cheap clay for pottery production was also a useful raw material for making porous ceramic plates for self-cooling by evaporation of absorbed water. ${ }^{17)}$

In this study, porous plates were prepared from Onggi

Corresponding author: Woo-Seok Cho

E-mail : wscho@kicet.re.kr

Tel : +82-31-645-1405 Fax : +82-31-645-1486 clay and bamboo charcoal powder by firing the two materials at 1100 and $1200^{\circ} \mathrm{C}$, and the role of the porous properties in self-cooling of these porous plates via evaporation of absorbed water was investigated. A simple and new cooling system using porous plates and water was proposed.

\section{Experimental Procedure}

\subsection{Preparation of porous ceramic plate from clay and bamboo charcoal powder}

Onggi clay for old Korean pottery was used for making porous plates, and two kinds of commercial bamboo charcoal powder with different particle sizes were separately mixed with clay to form pores in the plates after firing. The average particle sizes of Type A and B charcoals (Type A and Type B) were determined to be 67 and $140 \mathrm{~mm}$, respectively. The content of charcoal powder mixed with clay was $10 \mathrm{mass} \%$ and the water content in clay was 22.2 mass $\%$. The charcoal powder was well mixed with clay and then put in a gypsum mold $(65 \times 11 \times 8$, and $11 \times 11 \times 1 \mathrm{~cm})$ and pressed using $0.15 \mathrm{MPa}$ pressure to prepare clay and charcoal composites. After drying plates at $75^{\circ} \mathrm{C}$ for $12 \mathrm{~h}$, samples were fired at 1100 and $1200^{\circ} \mathrm{C}$ for $1 \mathrm{~h}$ to burn off charcoal powder under air atmosphere. The heating rate, up to 1100 and $1200^{\circ} \mathrm{C}$, was $150^{\circ} \mathrm{C} / \mathrm{h}$. Porous properties were analyzed using an Hg-Porosimeter (Model: Auto Pore IV, Micrometrics Instrument Co., USA) and the specific surface area was measured by BET method with nitrogen-gas as the adsorbent (Model: TriStar II, Micromeritics Instrument 
Co., USA). Minerals present in raw clay and fired plates were analyzed by X-ray diffraction (XRD) (Model: D/Max, 250, Rigaku Co., Japan). Chemical composition of clay was analyzed by X-ray fluorescence analysis (XRF)(Model: S1, TITAN, Bruker Co., USA). Microstructures of porous plates were observed using a field emission scanning electron microscope (FE-SEM) (Model: JSM-6390, JEOL Co., Japan).

\subsection{Water absorption and air cooling effect of porous ceramic plate}

Water absorption ability of porous plates fired at $1100^{\circ} \mathrm{C}$ was measured according to the moving rate of water from the bottom to top of porous plates at $27^{\circ} \mathrm{C}$ with $68 \%$ of relative humidity (R.H.). The porous plates were dried at $75^{\circ} \mathrm{C}$ for $24 \mathrm{~h}$ before water absorption test.

To investigate the cooling effect of porous plates via evaporation of absorbed water, 12 porous plates $(9.5 \times 9.5 \times 0.6$ $\mathrm{cm})$ fired at $1100^{\circ} \mathrm{C}$ were set parallel to air flow in an adiabatic closed box $\left(5400 \mathrm{~cm}^{3}, 25 \times 18 \times 12 \mathrm{~cm}\right)$ assembled with polystyrene foam plates, as shown in Fig. 1, and approximately $800 \mathrm{cc} / \mathrm{min}$ of air was continuously introduced into the closed box by a small fan. This experiment was carried out in a temperature- and humidity-controlled room $\left(\mathrm{ca} .60 \mathrm{~m}^{3}\right)$. The inlet air was introduced from an $8 \mathrm{~cm}$ diameter window into the closed box $\left(5,400 \mathrm{~cm}^{3}\right)$ by a small fan; the cooled air was discharged via a $4 \mathrm{~cm}$ diameter pipe (Fig. 1). The linear velocities of the inlet and outlet air were 15.9 and $63.7 \mathrm{~cm} / \mathrm{min}$, respectively. In Fig. 1(b), the introduced air can be seen to pass through a space $\left(250 \mathrm{~cm}^{3}\right)$ sur-
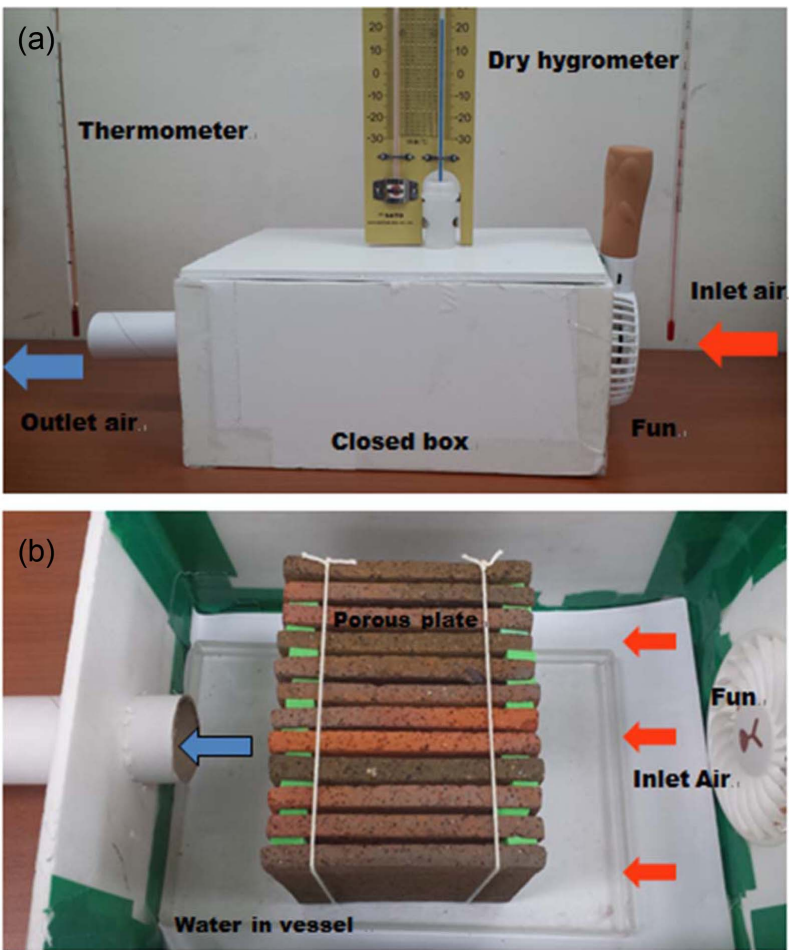

Fig. 1. Experimental method for measurement of self-cooling effect using porous ceramic plates. (a) outside and (b) inside of the closed box. rounded by 12 porous plates (distance of two porous plates: $0.3 \mathrm{~cm})$.

Temperatures at the inlet and outlet of the box were measured using a conventional glass thermometer. In this experiment, $200 \mathrm{~cm}^{3}$ of water was put into a plastic vessel $(20 \times 13 \times 3 \mathrm{~cm})$, which was set in the box; $1 \mathrm{~cm}$ of the lower part of the porous plate was dipped in water. Self-cooling tests were carried out at $25-30^{\circ} \mathrm{C}$ with $60-77 \%$ of R.H.

\section{Results and Discussion}

\subsection{Porous properties of fired Onggi clay plates}

The chemical composition of raw clay was determined to be as follows: $\mathrm{SiO}_{2}(56.05 \%), \mathrm{Al}_{2} \mathrm{O}_{3}(24.8 \%), \mathrm{Fe}_{2} \mathrm{O}_{3}(4.29 \%)$, $\mathrm{TiO}_{2}(0.57 \%), \mathrm{CaO}$ (0.39\%), $\mathrm{MgO}$ (2.67\%), $\mathrm{Na}_{2} \mathrm{O}$ (tr.), $\mathrm{K}_{2} \mathrm{O}$ (1.69\%) and loss of ignition (8.0 mass\%). This clay had a small amount of coarse a-quartz particles of 0.5 to $2 \mathrm{~mm}$ of diameter after elutriation treatment of clay in water.

Clay plates with Type A and B powder were fired at 1100 and $1200^{\circ} \mathrm{C}$ for $1 \mathrm{~h}$. Fig. 2 shows as-formed plates with two kinds of charcoal powder and the fired porous plates at $1100^{\circ} \mathrm{C}$. Fig. 3 shows microstructures of the plates fired at 1100 and $1200^{\circ} \mathrm{C}$. The sintering of the clay fired at $1200^{\circ} \mathrm{C}$ without charcoal powder (Fig. 3(b)) was promoted and formed glassy and round pores in the body due to bloating phenomenon. ${ }^{18)}$

Figure 4 shows XRD patterns of raw clay and clays fired at 1100 and $1200^{\circ} \mathrm{C}$. Raw clay was composed of a-quartz, kaolinite, K-feldspar and vermiculite. After firing at $1100^{\circ} \mathrm{C}$, mullite phase, which was formed by the thermal decomposition of kaolinite and residual feldspar phase, was confirmed. At $1200^{\circ} \mathrm{C}$, the plate was composed of a-quartz and mullite.

Figure 5 shows the pore-size distribution and porous properties of some porous ceramic plates fired at $1100^{\circ} \mathrm{C}$ in air with and without Type A and B powders. Plates fired without charcoal powder had porous structures with $20.9 \%$ of porosity and macropores; there was also a strong peak centered at around $1 \mathrm{~mm}$. With the addition of Type A and B

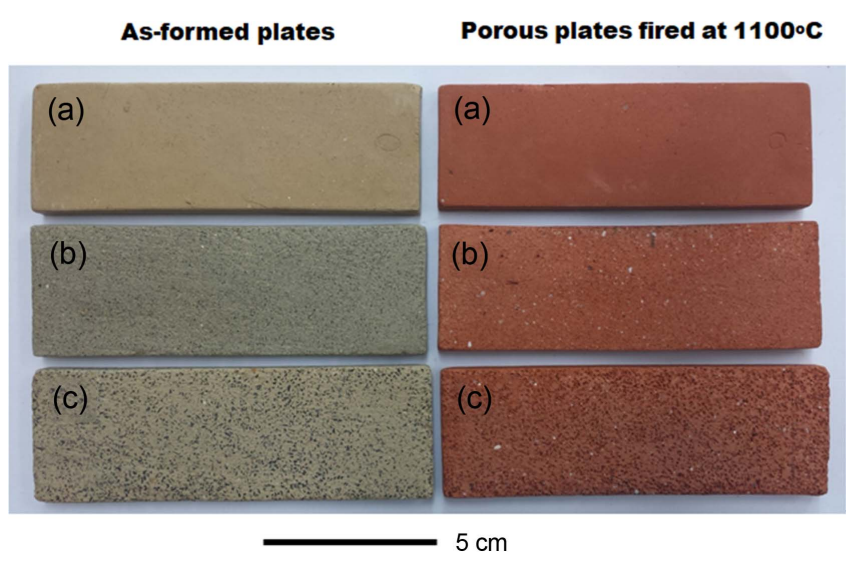

Fig. 2. As-formed Onggi clay plates with bamboo charcoal powder and porous plates fired at $1100^{\circ} \mathrm{C}$. (a) without charcoal powder, (b) with Type A and (c) with Type charcoal powder. 

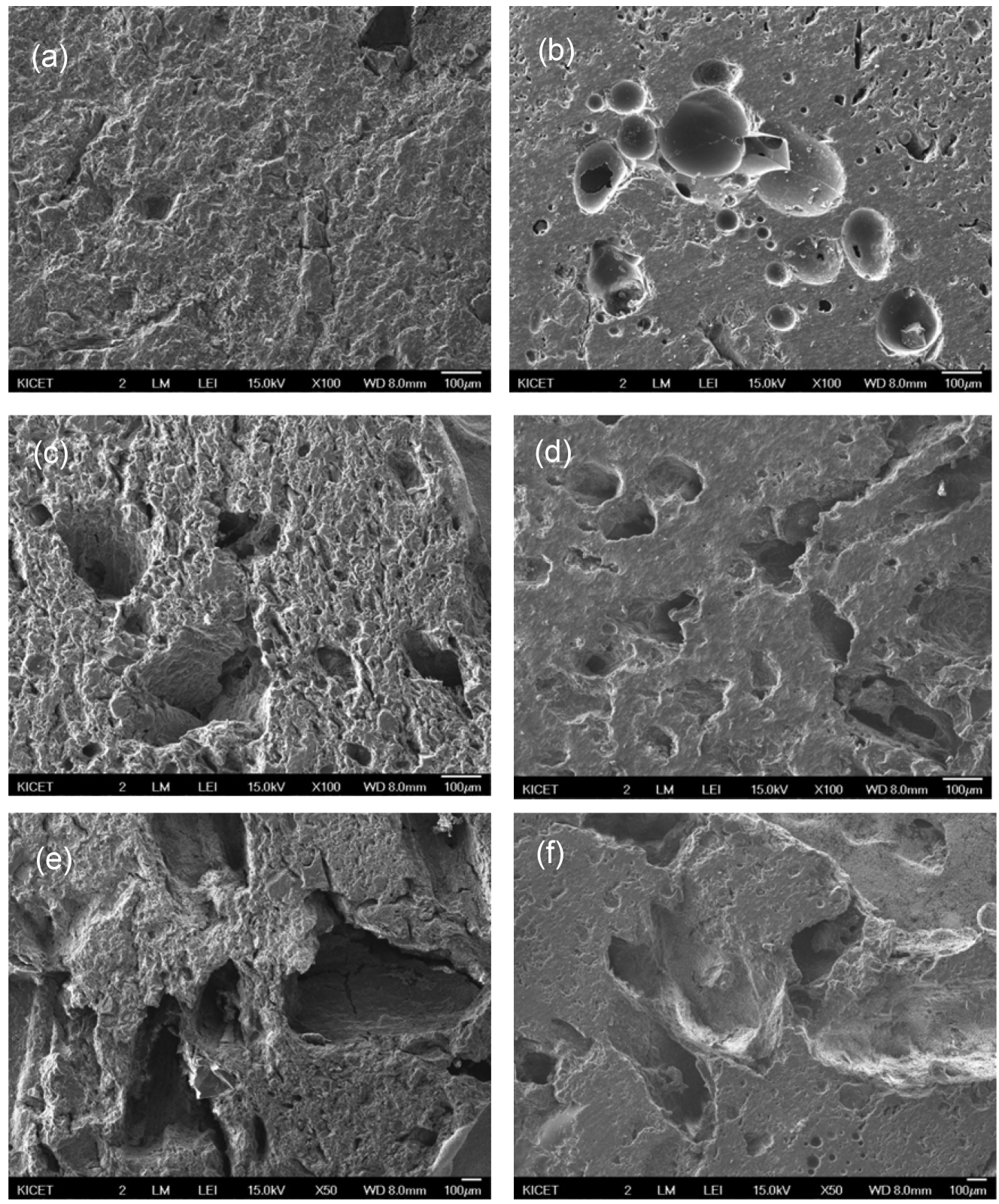

Fig. 3. Microstructure of porous plates fired at 1100 and $1200^{\circ} \mathrm{C}$ for $1 \mathrm{~h}$. (a), (c), and (e): fired at $1100^{\circ} \mathrm{C}$; (b), (d), and (f): fired at $1200^{\circ}$ C. (a) and (b): without carbon, (c) and (d): 10 mass\% Type A; (e) and (f): 10 mass\% Type B charcoal powder.

powders, porous plates had a duplex pore structure. Table 1 shows some properties of porous plates fired at 1100 and $1200^{\circ} \mathrm{C}$. With the addition of two kinds of charcoal powder, the pore structure was controlled after firing at 1100 and $1200^{\circ} \mathrm{C}$, as expected. Total pore volume and porosity, and bulk density of porous plates fired with two kinds of charcoal powder at 1100 and $1200^{\circ} \mathrm{C}$, decreased with firing temperature. The clay plates fired at 1100 and $1200^{\circ} \mathrm{C}$ without charcoal powder had porous structures with 0.11 and 0.05 $\mathrm{cm}^{3} / \mathrm{g}$ of total volume, 0.81 and $0.33 \mathrm{~mm}$ of average pore diameter, and 20.9 and $10.8 \%$ of porosity, respectively. With the addition of 10 mass\% of charcoal powder to the clay, porous plates with 1.27 and $2.56 \mathrm{~mm}$ of average pore diame- ter, 22.7 and $38.2 \%$ of porosity and 0.14 and $0.24 \mathrm{~cm}^{3} / \mathrm{g}$ of total volume were prepared from clay and Type A and B powders at $1100^{\circ} \mathrm{C}$, respectively. Furthermore, specific surface area values of porous plates fired at $1100^{\circ} \mathrm{C}$ from clay and clay with Type A and Type B powders were 0.15, 0.45, and $0.54 \mathrm{~m}^{2} / \mathrm{g}$, respectively. Porous plates with 1.17 and $2.03 \mathrm{~mm}$ of average pore diameter, 20.1 and $30.9 \%$ of porosity and 0.14 and $0.18 \mathrm{~cm}^{3} / \mathrm{g}$ of total volume were fired from clay and Type $\mathrm{A}$ and Type B powders at $1200^{\circ} \mathrm{C}$, respectively (Table 1). In this study, porous properties of plates fired with charcoal powder were mainly influenced by particle size of charcoal powder firing temperature, but final average pore sizes of porous plate fired using Type A and B pow- 

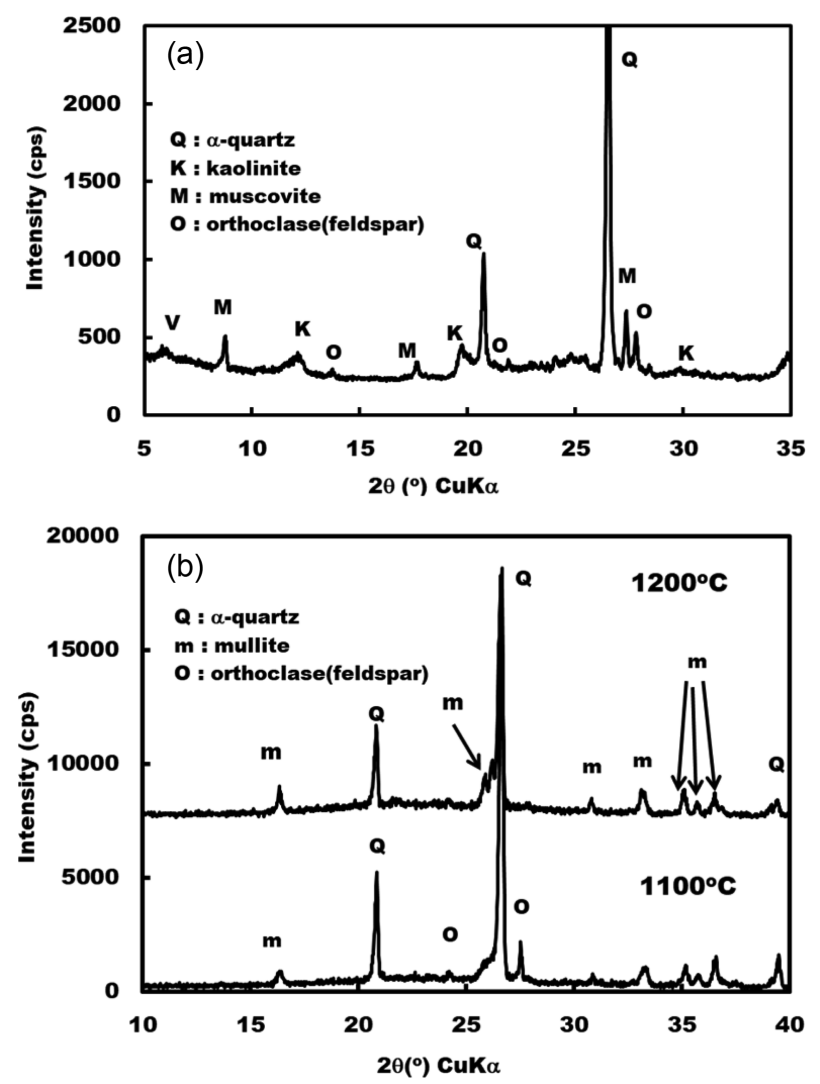

Fig. 4. XRD patterns of Onggi clay. (a) as-received, and (b) fired at 1100 and $1200^{\circ} \mathrm{C}$ for $1 \mathrm{~h}$ in air.

ders at 1100 and $1200^{\circ} \mathrm{C}$ did not depend on the 67 and 140 $\mathrm{mm}$ average particle sizes of the original Type A and B powdersThemairreasorfothidackoflependencefheporousproperties on the particle size of the bamboo charcoal powder was probably the breakdown of fragile charcoal particles into smaller particles during mixing and kneading with clay, and pressing in the gypsum mold. This phenomenon was confirmed in the case of wood charcoal powder. ${ }^{17}$ )

\subsection{Water absorption porous ceramic plates}

Figure 6 shows the method used to test the water absorption of porous plates fired at $1100^{\circ} \mathrm{C}$. Pictures were taken after water was poured for 8 minutes at $27^{\circ} \mathrm{C}$ and $68 \%$ of R.H. It took about 40 min (Type B powder), 100 min (Type A powder) and $180 \mathrm{~min}$ (without charcoal powder) for the top of porous plates to be saturated with absorbed water. Average moving rates of water from the bottom to the top of the porous plates fired without charcoal powder were $0.53 \mathrm{~mm} /$ min and 0.95 , and $2.4 \mathrm{~mm} / \mathrm{min}$ for plates fired with Type A and $B$ powders, respectively. Average moving rate of porous plates of Type B powder was 2 - 5 times faster than that of plates fired without charcoal powder. The amount of water absorbed in one porous plate after water reached the top of the plate prepared without charcoal powder was $13.1 \mathrm{~g}$; for plates prepared with Type A and B powders, the values were 13.5 and $15.2 \mathrm{~g}$.
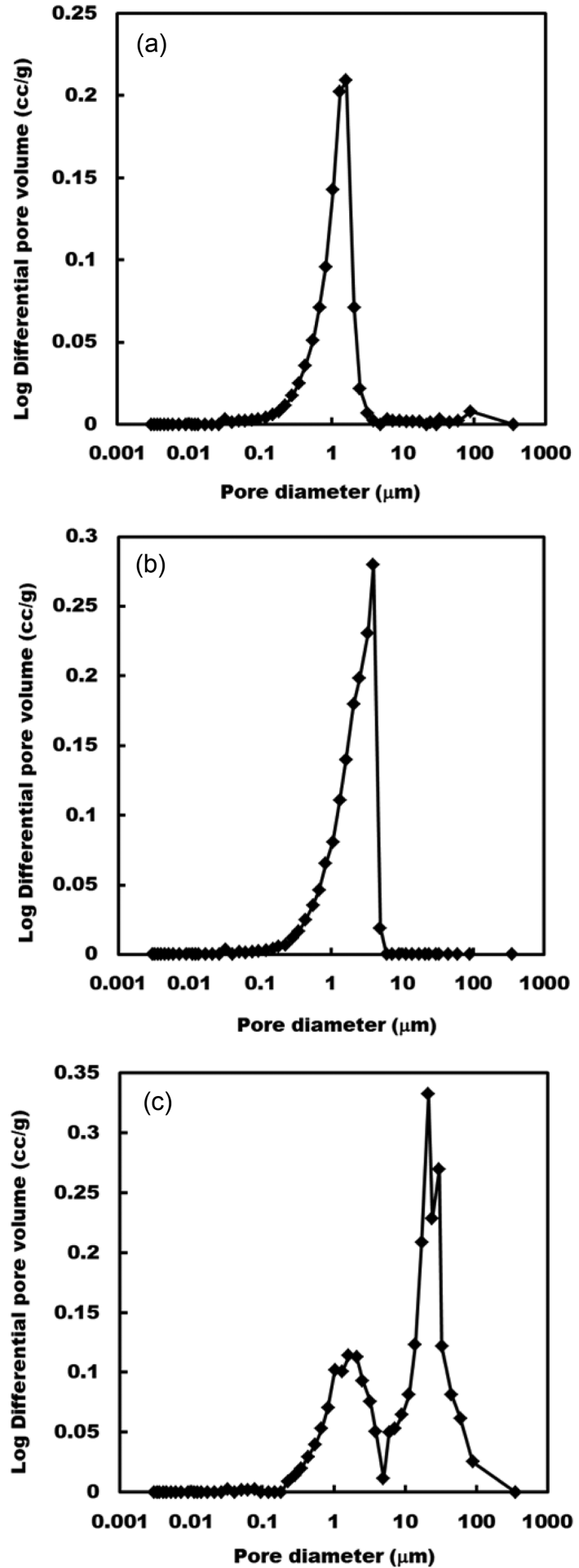

Fig. 5. Pore size distribution of ceramic plates fired from Onggi clay at $1100^{\circ} \mathrm{C}$ in air. (a) clay, (b) clay with Type A charcoal powder and (c) clay with Type B charcoal powder

3.3. Air cooling effect of porous plate via evaporation of absorbed water

Air cooling tests on porous plate surface were performed in an adiabatic closed box. The effect of the porous plate 
Table 1. Some Properties of Porous Ceramic Plates Fired from Onggi Clay and Bamboo Charcoal Powder at 1100 and $1200^{\circ} \mathrm{C}$

\begin{tabular}{ccccc}
\hline Samples & $\begin{array}{c}\text { Total pore volume } \\
\left(\mathrm{cm}^{3} / \mathrm{g}\right)\end{array}$ & $\begin{array}{c}\text { Porosity } \\
(\%)\end{array}$ & $\begin{array}{c}\text { Average pore diameter } \\
(\mu \mathrm{m})\end{array}$ & $\begin{array}{c}\text { Bulk density } \\
\left(\mathrm{g} / \mathrm{cm}^{3}\right)\end{array}$ \\
\hline $1100^{\circ} \mathrm{C}-0 \%$ & 0.11 & 20.9 & 0.81 & 2.03 \\
$1100^{\circ} \mathrm{C}-$ Type A & 0.140 & 22.7 & 1.27 & 1.63 \\
$1100^{\circ} \mathrm{C}-$ Type B & 0.243 & 38.2 & 2.56 & 1.57 \\
\hline $1200^{\circ} \mathrm{C}-0 \%$ & 0.049 & 10.8 & 0.33 & 2.21 \\
$1200^{\circ} \mathrm{C}$ - Type A & 0.136 & 20.1 & 1.17 & 1.78 \\
$1200^{\circ} \mathrm{C}$ - Type B & 0.182 & 30.9 & 2.03 & 1.70 \\
\hline
\end{tabular}

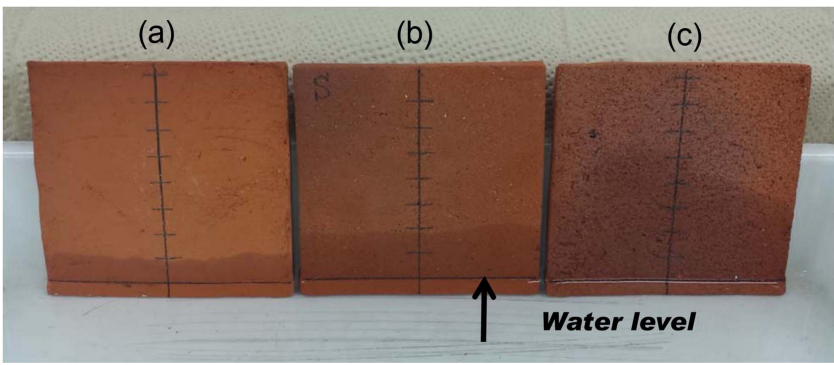

Fig. 6. Test of water absorption of ceramic porous plates fired at $1100^{\circ} \mathrm{C}$. (a) clay, (b) clay with Type A, and (c) clay with Type B charcoal powder.

structure on the air cooling effect was investigated. The porous plates were set parallel to the flow of introduced air (Fig. 1). Table 2 shows the effect of porous plates fired at $1100^{\circ} \mathrm{C}$ and R.H on air-cooling by water evaporation. Number of porous plates was 12 and distance between two plates was $3 \mathrm{~mm}$. The inlet air was introduced after the top of each plate was immersed in the absorbed water. Inlet air samples at temperatures and relative humidity levels of $26^{\circ} \mathrm{C}$ and $60 \%, 28^{\circ} \mathrm{C}$ and $77 \%$ and $30^{\circ} \mathrm{C}$ and $72 \%$ were introduced into the box; the temperature of the cooled air was measured at the outlet of the box. The temperatures at the inlet and outlet were measured every $10 \mathrm{~min}$ after introducing air; the average temperatures $\left(\mathrm{T}_{1}\right.$ and $\left.\mathrm{T}_{2}\right)$ were calculated and are shown in Table 2. By passing air through porous plates, cooled air at the outlet was obtained. Cooling effect values $\left(\Delta \mathrm{T}\right.$ ) were $0.8-1.3^{\circ} \mathrm{C}$ at $28^{\circ} \mathrm{C}$ (at $77 \%$ of R.H.), 1.4 $2.2^{\circ} \mathrm{C}$ at $30^{\circ} \mathrm{C}$ (at $72 \%$ of R.H.) and $2.3-3.6^{\circ} \mathrm{C}$ at $26^{\circ} \mathrm{C}$ (at $60 \%$ of R.H.). The cooling effect was dependent on R.H. and the porous properties of the added charcoal powder. It was possible to obtain cooled air $\left(\Delta \mathrm{T}=3.5-3.6^{\circ} \mathrm{C}\right)$ using porous plates fired from clay with Type A and B charcoal powders at $60 \%$ of R.H. and $26^{\circ} \mathrm{C}$ (Table 2). Porous plates fired from clay without charcoal powder showed a cooling effect lower than that of porous plates prepared from clay with Type A and $\mathrm{B}$ charcoal powders. Porous plates fired from clay with Type B powder at $1100^{\circ} \mathrm{C}$ had higher total pore volume, average pore diameter, and porosity than those characteristics of porous plates fired from clay with Type A powder (Table 1). The average evaporation rates of absorbed water from the surface of one porous plate over $3 \mathrm{~h}$ at $25^{\circ} \mathrm{C}$ with $60 \%$ of R.H. was $7.9 \mathrm{~g} / \mathrm{min}$ for the porous plate fired from clay without charcoal powder, $13.3 \mathrm{~g} / \mathrm{min}$ for the plate fired from clay with Type A powder, and $14.1 \mathrm{~g} / \mathrm{min}$ for the plate fired from clay with Type B powder. From these results, it can be seen that the evaporation rate of water from the surface of porous plates has an important role in generating cooled air by evaporation of absorbed water.

Table 3 shows the effects of stacking of porous plates and of the distance between two porous plates fired at $1100^{\circ} \mathrm{C}$ from clay with Type B powder on air cooling by water evaporation. With increasing humidity in the inlet air, the selfcooling effect $(\Delta \mathrm{T})$ decreased due to suppression of water evaporation from the surface of the porous plates. 12 stacked

Table 2. Effect of Relative Humidity and Temperature of Inlet Air on Self-Cooling by Water Evaporation of Porous Ceramic Plates Fired at $1100^{\circ} \mathrm{C}$

\begin{tabular}{|c|c|c|c|c|}
\hline \multirow[b]{2}{*}{ Samples } & \multirow{2}{*}{$\begin{array}{l}\text { Relative humidity } \\
\text { of inlet air (\%) }\end{array}$} & \multicolumn{3}{|c|}{ Temperature $\left({ }^{\circ} \mathrm{C}\right)$} \\
\hline & & $\begin{array}{c}\text { Inlet air } \\
\left(\mathrm{T}_{1}\right)\end{array}$ & $\begin{array}{c}\text { Outlet air } \\
\left(\mathrm{T}_{2}\right)\end{array}$ & $\begin{array}{l}\text { Cooling effect } \\
\Delta \mathrm{T}=\mathrm{T}_{1}-\mathrm{T}_{2}\end{array}$ \\
\hline Clay & 77 & 28 & 27.2 & 0.8 \\
\hline Clay + Type A & 77 & 28 & 26.9 & 1.1 \\
\hline Clay + Type B & 77 & 28 & 26.7 & 1.3 \\
\hline Clay & 72 & 30 & 28.6 & 1.4 \\
\hline Clay + Type A & 72 & 30 & 27.8 & 2.2 \\
\hline Clay + Type B & 72 & 30 & 27.9 & 2.1 \\
\hline Clay & 60 & 26 & 23.7 & 2.3 \\
\hline Clay + Type A & 60 & 26 & 22.5 & 3.5 \\
\hline Clay + Type B & 60 & 26 & 22.4 & 3.6 \\
\hline
\end{tabular}


Table 3. Effect of Stacking of Porous Ceramic Plates Fired at $1100^{\circ} \mathrm{C}$ with Type B Charcoal Powder on Self-Cooling of Inlet Air at 64 and $68 \%$ of Relative Humidity

\begin{tabular}{cccccc}
\hline \multirow{2}{*}{$\begin{array}{c}\text { Relative humidity } \\
\text { of inlet air (\%) }\end{array}$} & \multicolumn{2}{c}{ Stacked porous plates } & \multicolumn{3}{c}{ Temperature of air $\left({ }^{\circ} \mathrm{C}\right)$} \\
\cline { 2 - 6 } & $\begin{array}{c}\text { Stack } \\
\text { number }\end{array}$ & $\begin{array}{c}\text { Plates distance } \\
(\mathrm{mm})\end{array}$ & $\begin{array}{c}\text { Inlet } \\
\left(\mathrm{T}_{1}\right)\end{array}$ & $\begin{array}{c}\text { Outlet } \\
\left(\mathrm{T}_{2}\right)\end{array}$ & $\begin{array}{c}\text { Cooling effect } \\
\Delta \mathrm{T}=\mathrm{T}_{1}-\mathrm{T}_{2}\end{array}$ \\
\hline 64 & 12 & $<1$ & 25.2 & 23.4 & 1.8 \\
64 & 12 & 3 & 25.1 & 22.2 & 2.9 \\
64 & 6 & 3 & 25.0 & 23.2 & 2.8 \\
64 & 6 & 10 & 25.2 & 22.8 & 2.4 \\
70 & 12 & $<1$ & 27.1 & 26.6 & 2.6 \\
70 & 12 & 3 & 27.2 & 24.6 & 2.5 \\
70 & 6 & 3 & 27.1 & 25.7 & 2.0 \\
\hline
\end{tabular}

porous plates with narrow distance $(<1 \mathrm{~mm})$ between them showed a lower self-cooling effect $\left(\Delta \mathrm{T}=1.5^{\circ} \mathrm{C}\right.$ at $27^{\circ} \mathrm{C}$ with $70 \%$ of R.H. and $\Delta \mathrm{T}=1.8^{\circ} \mathrm{C}$ at $25^{\circ} \mathrm{C}$ with $64 \%$ of R.H.). With increasing of the distance between stacked plates, contact of inlet air with the surface of the plate was promoted, enhancing the cooling effect of water evaporation. Furthermore, the self-cooling effect was promoted with increasing of the number of the stacked porous plates, as expected.

In this study, the effects of the properties of porous ceramic plates, and of the number and distance between plates fired at $1100^{\circ} \mathrm{C}$ from Onggi clay and charcoal powder, on self-cooling of air was investigated. Study is in progress of the effects of the thickness of porous plate, surface roughness of plate and contact method of inlet air and porous plates on the high self-cooling effect of this simple and ecofriendly system.

\section{Conclusions}

In this paper, some porous ceramic plates formed using Onggi clay and bamboo charcoal powder were prepared at 1100 and $1200^{\circ} \mathrm{C}$, and certain porous properties, including the water absorption and the cooling effect, according to the evaporation of absorbed water in a closed box, were investigated to produce an eco-friendly and simple cooling system. Porous properties were dependent on the firing temperature and the addition of wood charcoal powder. Total pore volume, average pore size and porosity were $0.11-0.243 \mathrm{~cm}^{3} / \mathrm{g}$, $0.81-2.56 \mu \mathrm{m}$ and $20.9-38.2 \%$, respectively at $1100^{\circ} \mathrm{C}$, and $0.049-0.182 \mathrm{~cm}^{3} / \mathrm{g}, 0.33-2.03 \mu \mathrm{m}$ and $10.8-30.9 \%$, respectively at $1200^{\circ} \mathrm{C}$. Self-cooling effect of porous ceramic plate with absorbed water was investigated under flowing air in a closed box; effect was found to be dependent of porous properties and relative humidity of inlet air. Porous ceramic plates with $22.7-38.2 \%$ of porosity and $1.27-2.56 \mu \mathrm{m}$ of pore diameter were found to be able to produce cooled air with $3.5-3.6^{\circ} \mathrm{C}$ of temperature drop at $26^{\circ} \mathrm{C}$ and $60 \%$ of relative humidity. The self-cooling effect was promoted with increasing of the number of stacked porous plates and distance between plates.

\section{Acknowledgments}

This study was supported by the Ceramicware Center of the Korea Institute of Ceramic Engineering \& Technology, under grant number 17-BUS010025000 (Establishment of new Value Ceramicware Industry Base).

\section{REFERENCES}

1. T. Sugiyama, K. Kusumoto, M. Ohashi, and A. Kamiya, "Environmental Friendly Ceramic Building Materials," Key Eng. Mater., 690 150-55 (2016).

2. T. Kato, K. Ohsashi, M. Fuji, and M. Takahashi, "Water Absorption and Retention of Porous Ceramics Fabricated by Waste Resources," J. Ceram. Soc. Jpn., 116 [1350] 21215 (2008).

3. K. Okada, Y. Kameshima, A. Nakashima, and C. D. Madhusoodana, "Preparation of Lotus-Type Porous Ceramics with High Water Pump-Up Ability and its Cooling Effect by Water Vapor Evaporation (in Japanese)," J. Heat Island Inst. Int., 2 1-5 (2007).

4. A. Hoyano, J. He, S. Ogawa, J. Ando, S. Yamamura, H. Akagawa, K. Nakajima, K. Okada, and T. Kurata, "Development of an Evaporative Cooling Wall Constructed of Porous Ceramics with High Water Soaking up Ability (in Japanese)," J. Environ. Eng., 74 [641] 775-82 (2009).

5. H. T. M. Thu and H. Sato, "Proposal of an Eco-Friendly High-Performance Air-Conditioning System. Part 1. Possibility of Improving Existing Air-Conditioning System by an Evapo-Transpiration Condenser," Int. J. Refrig., 36 [6] 1589-95 (2013).

6. H. T. M. Thu and H. Sato, "Proposal of an Eco-Friendly High-performance air-conditioning system. Part 2. Application of Evapotranspiration Condenser to Residential Air-Conditioning System," Int. J. Refrig., 36 [6] 1596-601 (2013).

7. V. O. Aimiuwa, "Evaporative Cooling of Water in Hot Arid Regions," Energy Convers. Manage., 33 [1] 69-74 (1992).

8. B. Mohan and S. Konatham, "Advanced Hollow Pipes Made of Ceramic Air Cooler," IJMETMR, 3 [4] 72-7 (2016).

9. J. He and A. Hoyano, "Experimental Study of Cooling Effects of a Passive Evaporative Cooling Wall Constructed 
of Porous Ceramics with High Water Soaking-up Ability," Build. Environ., 45 [2] 461-72 (2010).

10. E. Anyanwu, "Design and Measured Performance of a Porous Evaporative Cooler for Preservation of Fruits and Vegetables,” Energy Convers. Manage., 45 [13-14] 2187-95 (2004).

11. S. Riffat and J. Zhu, "Mathematical model of indirect evaporative cooler using porous ceramic and heat pipe," Appl. Therm. Eng., 24 [4] 457-70 (2003).

12. S. Riffat and J. Zhu, "Experimental Investigation of an Indirect Evaporative Cooler Consisting of a Heat Pipe Embedded in Porous Ceramic," J. Eng. Res., 1 [1] 46-52 (2004).

13. W. Chen, S. Liu, and J. Lin, "Analysis on the Passive Evaporative Cooling Wall Constructed of Porous Ceramic Pipes with Water Sucking Ability," Energy Build., 86 54149 (2015).

14. E. Velasco Gomez, F. Rey Martinez, F. Varela Diez, M.
Molina Leyva, and R. Herrero Martin, "Description and Experimental Results of a Semi-Indirect Ceramic Evaporative Cooler," Int. J. Refrig., 28 [5] 654-62 (2005).

15. A. Mittal, T. Kataria, G. K. Das, and S. Chatterjee, "Evaporative Cooling of Water in a Small Vessel under Varying Ambient Humidity," Int. J. Green Energy, 3 [4] 347-68 (2006).

16. J. H. Park, J. H. Kim, W. S. Cho, K. S. Han, and K. T. Hwang, "Fabrication and Characterization of Onggi Filter for Appropriate Water Treatment Technology," J. Korean Ceram. Soc., 54 [2] 114-20 (2017).

17. H. Katsuki, E. K. Choi, W. J. Lee, K. T. Hwang, W. S. Cho, and S. Komarneni, "Effect of Porous Properties on SelfCooling of Fired Clay Plate by Evaporation of Absorbed Water," J. Porous Mater., (in press).

18. Y. Kobayashi, O. Ohira, Y. Ohashi, and E. Kato, "Effect of Firing Temperature on Bending Strength of Porcelains for Tableware," J. Am. Ceram. Soc., 75 [7] 1801-6 (1992). 